Article

\title{
Sciencey Girls: Discourses Supporting Working-Class Girls to Identify with Science
}

\author{
Spela Godec \\ UCL Institute of Education, University College London, 20 Bedford Way, Bloomsbury, London WC1H 0AL, UK; \\ s.godec@ucl.ac.uk
}

Received: 30 November 2017; Accepted: 6 January 2018; Published: 23 January 2018

\begin{abstract}
Women from working class and some ethnic minority backgrounds continue to be underrepresented in science, particularly in areas such as physical sciences and engineering. Many find it difficult to see science as something that is "for them", which then has implications for their learning and participation in science. In this paper, I discuss findings from a U.K.-based qualitative study with 15 working-class girls, aged 11 to 13, from diverse ethnic backgrounds. Data were collected over the course of one academic year, through interviews and discussion groups with the girls and interviews with their science teachers, and analysed through a post-structural gender lens. The paper foregrounds five science-identifying girls, who negotiated their identification and engagement with science through the following discursive strategies: (i) rendering gender invisible, (ii) drawing attention to the presence of women in science, (iii) reframing "science people" as caring and nurturing, and (iv) cultural discourses of desirability of science. The findings contribute to the understanding of how working class girls-who are often "othered" and constructed as "unintelligible" within the dominant discursive regime of prototypical science-find identification with science possible. The paper discusses the affordances and challenges of each discursive strategy.
\end{abstract}

Keywords: identification with science; working class; girls; gender; performativity; discourse

\section{Introduction: Identification with Science and Its Potential for Examining Social Equity Issues in Science Education}

Studying how learners identify with science is important for understanding their learning and participation. To echo Brickhouse and Potter: "if students are to learn science, they must develop identities compatible with scientific identities" [1] (p. 443). Students who see science as something that is-or could be-for them are likely to engage more with the subject [2-4]. On the other hand, those who see science as being in conflict with who they are and want to become might experience difficulties engaging with science. The latter are also more likely to risk school science failure and opt out from participating in post-compulsory science courses, as well as pursuing science-related careers [5,6]. The notion of identifying with science can complement other constructs that have been linked with science participation, such as interest and attitudes towards science [7-11]. Considering how learners identify with science is particularly valuable in light of research findings showing that having high interest and appreciation for science does not necessarily translate into wanting to participate in science in the future [12]. Over the last two decades, there has been an increased focus on identity research in science education. Studies have included learners from different age groups; from primary school [12], secondary or high school [1,2,13-15], to higher education [16-19] and into employment $[20,21]$. Research findings pertaining to how people identify with science have also increasingly been taken up by science education policy and practice. In the U.K., for instance, examples include organisations like the Institute of Physics [22,23] and the Women in Science and Engineering Campaign [24], which have promoted and designed interventions around supporting more young people to see themselves in science. 
My particular interest in working with the notion of identification with science lies in its potential to explore social equity issues in science education. The profile of who continues with science into further education and employment shows stratification along multiple social axes, in favour of the demographic group most closely associated with the sociohistorical legacy of science: white, middle-class men [25-27]. Inequalities in science participation are a social justice issue, as well as a concern for the future supply of skilled workforce and national economic competitiveness [28-30]. Due to dominant associations of science with rationality, objectivity, and cleverness-which contribute to the construction of science as a masculine subject-it is easier for some people to identify with science than it is for others [31-35]. It tends to be more difficult to identify with science for those who perform femininity (who are predominantly girls/women). As Archer et al. [36] have argued, science is perceived as not "girly", "sexy" or "glamorous" enough to fit with many girls' desirable performances of femininity. Labels like "boffin" and "geek", commonly associated with high academic achievers and those who are "good" at school science, further contribute to undesirability of the subject $[37,38]$. The challenges of negotiating their positioning in science are increased for girls from working-class backgrounds. It has been suggested that those performing typically working-class "girly" femininity experience particular tension with masculinity that is dominantly associated with science, and are among least likely to aspire to careers in science [10]. Working-class girls also tend to possess lower levels of dominantly-valued "science capital", making it further difficult to see science as something that people like them do [39-41]. Finally, identification with science has been argued to be additionally complicated by ethnicity, which presents an "additional burden" for many girls' and women's engagement and participation in science [2,3,18,42].

The study presented in this paper focuses on working class, ethnically diverse girls aged 11-13 (from the first two years of secondary schooling in the U.K., Year 7 and Year 8). This age was selected because research has shown that already, at the start of secondary schooling, many young people hold strong views whether science is or is not for them [36,43]. Research with this demographic group has predominantly focused on examining the difficulties for engagement and identification with science [2,36,42], with fewer studies exploring how students are making identification with science possible. In this paper, I hope to contribute to the education literature by addressing the following research question: how do working-class, ethnically diverse girls negotiate their identification with science?

\section{Theoretical Framework: Gender Performativity and Gender Intelligibility}

To examine and understand discourses enabling and supporting identification and engagement with science, I draw on post-structural feminist theory. This conceptual framing includes Judith Butler's $[44,45]$ theories of gender performativity and gender "intelligibility", and integrates an intersectional approach, in order to be able to attend to the interactions of gender with social class and ethnicity $[46,47]$. Gender is regarded as performed (something we "do" rather than something we "are") and discursively produced. In Butler's words, "[t]here is no gender identity behind the expressions of gender" [45] (p. 3). Gender is not a "consequence" of a person's biological sex, and it is not fixed and stable. Gender identity is maintained by the repetition of performative acts, which over time become largely subconscious. This means that people might not always be aware that they are "doing" gender. As Renold has elaborated on Butler's theorisation, "gender is actualized through a series of repetitive performances that constitute the illusion of a 'proper,' 'natural,' or 'fixed' gender" [48] (p. 4).

Despite the performative nature of gender, people are not completely free to perform gender in whatever way they like. Gender performances are influenced and shaped by social pressures and expectations. Butler [44] (p. 232) has argued that rather than a product of free choice, such acts are a "forcible citation of a norm, one whose complex history is indissociable from relations of discipline, regulation, punishment". Performances of gender and identity are considered "intelligible" when they are aligned with societal expectations for a person of a particular biological sex. This involves 
those labelled female performing femininity, and those labelled male performing masculinity. "Intelligibility" of performances, furthermore, depends on the interactions of gender with other social axes, as performative acts might be differently aligned with socially-desired femininity for girls from different social backgrounds [49-53]. Working-class performances of femininity may therefore be judged differently from middle-class ones, and these may further be mediated by what performances are considered appropriate for girls from particular ethnic minority backgrounds. A socially desirable identity performance might be quite different for a white, British, working-class girl than for a Muslim, South Asian, middle-class girl. Butler has not limited the theory of performativity and "intelligibility" to gender, but has extended it to include other social axes, as "the regulatory practices that govern gender also govern culturally intelligible notions of identity" [45] (p. 23). Identity performances are differently supported, valued, and recognised within specific contexts-such as, for example, in a science classroom. The performances that are considered "intelligible" within a context of a typical science class may not be "intelligible" and socially desirable for girls, and vice versa. If subjectivities of science are not compatible with gender subjectivities, identification and engagement with science might be difficult.

If being a scientist is congruent with gender subjectivities available within dominant discourses and practices of science, a scientist identity is relatively easy for a student to construct. However, if the subjectivities are not compatible, a scientist identity is uncomfortable and may be rejected. [54] (p. 278)

Given that research suggests that many working-class girls resist or reject "scientist identity" due to its incompatibility with their gender (and class or ethnic) subjectivities, exploring how some are able to "go against the grain" could provide a useful insight into the negotiations of identification with science.

\section{About this Study: Participants, Data Collection, and Data Analysis}

The present study was conducted as part of a larger five-year Enterprising Science project aiming to broaden and increase diverse young people's engagement with science. Ethical approval for this study was gained from research ethics panel at King's College London, and the research followed the professional codes of conduct specified by the British Sociological Association and the British Educational Research Association. The study focused on a group of 15 girls from lower socioeconomic and diverse ethnic backgrounds, who were recruited from inner-city schools in London (one Year 7 science class) and Manchester (one Year 8 science class). According to the Office for Standards in Education, Children's Services, and Skills reports, both schools had a higher than national average proportion of students eligible for free school meals (in the U.K., a free school meal is a statutory benefit available to school-aged children from families with low income, or who receive other qualifying benefits) and students who spoke English as an additional language. All students in one selected science class at each school were invited to participate, and consent was sought from both the parents and the students. Fifteen girls were selected to participate in the study. The decision was made on the basis of the amount of data collected and the girls' socioeconomic background. For instance, some girls only consented to participate later in the academic year, meaning that less data were collected for them. My aim was to focus on girls from working-class backgrounds, although I acknowledge that social class in an ambiguous concept (also mediated by the recent history of migration, which often contributes to downward social mobility, see [55-57]). In selecting the participants for this study, I considered data on parental education and occupation, and use the label "working-class" to indicate socioeconomic disadvantage.

This paper draws on data collected through nine discussion groups with students $(n=12$ students), 14 individual interviews with students, and eight interviews with teachers $(n=4$ teachers), carried out over the period of one academic year. Seven girls took part in a discussion group twice, at the beginning and at the end of the school year. The interviews and discussion 
groups usually took place in an empty classroom or an office, before or after the science lessons. Discussion groups were purposefully small-including between three and six participants-to enable in-depth conversations [58]. These small group sessions provided a more social, comfortable environment in comparison to one-to-one interviewing [59]. Interviews, which I conducted towards the end of the school year, afforded space to discuss views and opinions that the girls may not have felt comfortable sharing within a group, and enabled me to prompt any issues from previous conversations and the ongoing data analysis. The interview and discussion group schedules were semi-structured to allow for flexibility while also covering a set of pre-designed questions [59,60]. The girls were asked, for instance, about their views of science and "science people", their aspirations and their engagement with science in and outside school. In addressing the research question posed in this paper, I focus predominantly on the girls' data, but I also consider data collected during teacher interviews, where I regard their comments as contributions to the understanding of the influences and negotiations of the girls' identification with science.

I began analysing data by mapping out the girls' identification and engagement with science, as well as their aspirations. Five girls self-identified with science and aspired to continuing with science post-16 (in careers in and from science, see [61]): Amna, Asqa, Dorota, Sharifa, and Samira (see Table 1 for details). I then examined the discourses [62] that I interpreted as supporting the girls identifying as "sciencey" and engaging with science, such as how they constructed science as a subject, how they spoke about "science people" and how they constituted their participation in science as "intelligible". These discourses were constructed through my interaction with the girls I interviewed. I see discourses as sets of meanings that construct particular subjectivities, and in these I focused on how the girls took up the discourses to position themselves within or outside science (attending also to their various constructions of science) [63]. I use the term "discursive strategy" to denote a discourse that played a role of enabling and supporting the girls to identify with science, and position themselves as "intelligible" subjects within science. During the process of data analysis I was asking questions: What is a discourse normalising? What is it "doing" to support the girls' identification with science? What constructions of science or "science people" might a particular discursive strategy be excluding? Drawing on Burman and Parker's work on discourse analytical approach, I kept the interpretative process of data analysis as open as possible, as "[t]o introduce closure is to do violence to the variety of possible interpretations that could be given of the text when it comes to life in a discourse analytic reading" [62] (p. 157).

Table 1. Data about the girls in the study cohort who identified with science.

\begin{tabular}{|c|c|c|c|c|}
\hline $\begin{array}{c}\text { Girls } \\
\text { (Pseudonyms) }\end{array}$ & $\begin{array}{c}\text { School } \\
\text { (Pseudonyms) }\end{array}$ & Year Group (Age) & $\begin{array}{c}\text { Ethnic } \\
\text { Background }\end{array}$ & Aspiration \\
\hline Amna & $\begin{array}{l}\text { Longdale High, } \\
\text { Manchester }\end{array}$ & Year 8 (12 years old) & British-Bangladeshi & $\begin{array}{l}\text { Something } \\
\text { science-related } \\
\text { (unspecified) }\end{array}$ \\
\hline Asqa & $\begin{array}{l}\text { Longdale High, } \\
\text { Manchester }\end{array}$ & Year 8 (12 years old) & Pakistani & $\begin{array}{c}\text { Doctor, pharmacist } \\
\text { or dentist }\end{array}$ \\
\hline Dorota & $\begin{array}{l}\text { Longdale High, } \\
\text { Manchester }\end{array}$ & Year 8 (12 years old) & $\begin{array}{l}\text { Kurdish-Eastern } \\
\text { European }\end{array}$ & $\begin{array}{l}\text { Doctor or } \\
\text { astronomer }\end{array}$ \\
\hline Samira & $\begin{array}{l}\text { Northfields School, } \\
\text { London }\end{array}$ & Year 7 (11 years old) & Arabic (Iraqi) & Research scientist \\
\hline Sharifa & $\begin{array}{l}\text { Northfields School, } \\
\text { London }\end{array}$ & Year 7 (11 years old) & Pakistani & $\begin{array}{c}\text { Scientist or science } \\
\text { teacher }\end{array}$ \\
\hline
\end{tabular}

Coding of gendered performances and discourses was informed by the extensive literature on characteristics typically or traditionally associated with masculinity and femininity [27,64], whereby "femininity and masculinity [are] linked directly to the dualist construction of sexed bodies as male and female", with "dominant binary understandings of masculinity as rational, strong, active and 
femininity as emotional, weak, passive" [64] (p. 479). My analysis of the data generated four key discursive strategies, which I suggest enabled the five girls to identify with science: (i) rendering gender invisible, (ii) drawing attention to the presence of women in science, (iii) reframing "science people" as caring and nurturing, and (iv) cultural discourses of desirability of science. I contextualised these findings by considering the extent to which similar or contradictory discourses were articulated by the other girls, who did not identify with science $(n=10)$.

\section{Findings and Discussion: Discursive Strategies Enabling Girls' Identification with Science}

\subsection{Egalitarian Discourse of "Science for Everyone"}

The girls across the cohort $(n=15)$ largely shared the egalitarian idea that science was "for everyone" and that "anyone can do science". As one of the girls (Alimah) put it, "it's not about what gender you are, it's just you have to learn the stuff" in order to do well and participate in science. Others agreed that gender did not play a role in science participation or education more broadly. Layla said that she and her peers "don't have the opinion of girls do this and boys do this". Her classmate Rifat acknowledged that there were certain stereotypes associated with gender and science, but argued that she did not adopt such thinking herself, adding that it was in fact "rude" of me to even ask her about this.

Science is for both boys and girls, it's not like only boys can do science. ... I know it's stereotypically going that men are more likely to become scientists than women. To be honest, science is for everyone, it doesn't really matter if you're male or female if you become a scientist or not. It is kind of rude [to ask] actually ...

-Rifat (Discussion group, March 2015)

For most of the girls in the study, gender issues appeared to not "matter" in terms of who participated in science. They also rejected the idea that being female had anything to do with being "sciencey". I interpreted these data as suggesting a discourse of equal opportunity and gender equality, which could be seen as "tied to academic ideal of individuality and independence" [16] (p. 34). This view positions individuals as responsible for their own success, which they can achieve through hard work and persistence [65]. Research has pointed out, however, that although students might reject the idea that gender plays a role in their educational experiences and achievements, their discourses often reflect stereotypical constructions of gender differences [66].

The girls' discourse of "science for everyone", however, did not necessarily extend to their own identification with science. Ten out of 15 girls in this cohort had science-related aspirations, or wanted to pursue careers that required post- 16 science education, but only five identified with science in that they considered themselves to be "sciencey". Rifat, for instance, who in the above quote argued that it was "rude" of me to suggest that gender influenced science participation, was a keen science student (she described science as her "best subject"), enjoyed science, and aspired to become a games designer in the future. However, Rifat did not identify with science: "I'm not a science person but I enjoy it. Because, I'm OK at science but I'm not that good." As this quote illustrates, Rifat associated science with cleverness and high academic achievement, which contributed to distancing herself from the subject. There were many factors hindering the girls' identification and engagement with science [67]. The purpose of this paper is not to focus in depth on the various reasons that constrained the girls' identification with science, but rather on the discursive strategies that enabled and supported the girls in making such identification possible. Next, I present the four discursive strategies, along with their challenges and limitations, and discuss the findings in relation to existing research work.

\subsection{Discursive Strategy One: Rendering Gender Invisible}

The first discursive strategy identified consisted of rendering gender "invisible". It could be illustrated by Samira's description of her participation in an afterschool STEM (science, technology, 
engineering and mathematics) club. Samira was a high achieving science student, who aspired to work as a scientist. When asked about her out-of-school science participation, Samira mentioned going to a STEM club at her school. Prompted to comment on the ratio of boys and girls in the club, she responded that she was usually the only girl, adding that she had not noticed this until I asked her. Further, she also speculated that no one else noticed gender either.

Me: What's the ratio of boys and girls in the [STEM] club?

Samira: More boys than girls, I think. Sometimes I'm the only girl ... they come sometimes, but not always, but I usually go like regularly.

Me: How does it feel to be the only girl in the STEM club?

Samira: I didn't really notice until you asked me, because I didn't really ... I don't think anyone really notices, because we're all like into science. It's not about gender, it's more about the learning part of it. (Interview, March 2015)

Samira appeared to have constructed gender as an invisible factor in science participation. This discursive strategy seemed to have enabled her to better fit in with the group of boys in the STEM club; if gender (supposedly) did not get noticed, there was less chance of her standing out as being "an anomaly" [16]. Studies have previously reported how some girls who encounter male-dominated science environments, where they were the only female, subsequently self-excluded from these spaces [68]. I suggest that drawing on the discourse of gender invisibility thus supported Samira in constructing her participation as more "intelligible".

The discourse of gender invisibility presents gender as a non-issue and extends the egalitarian discourse of "science for everyone". Data analysis, however, raises concerns about whether Samira was able to participate in science as a girl. During the interview, Samira positioned herself against typical performances of femininity enacted by her classmates. She spoke about a group of "popular girls" in her class-who called themselves a "Beyoncé group" (Beyoncé is an American singer, songwriter, dancer, and actress), reflecting their interest in fashion, pop culture, and Beyoncé's music-in derogatory ways, saying that these girls were only interested in "fame and money", "entertainment", "show[ing] each other off", and wanted "everyone to know about them". Samira, on the other hand, poised herself as being more interested in the "actual facts" that they were learning at school. She added that becoming a research scientist would enable her to do "loads of things that you wouldn't really get to do, if you were a celebrity or if you were like a singer or an actress or something", which I interpreted as Samira denoting the latter as an inferior option. I suggest that Samira rejected performances associated with typical working-class femininity, which she positioned in opposition with the "factual" (logical, rational) science $[17,36,65]$. The discourse of rendering gender invisible might therefore entail a risk that girls are expected to adjust to traditionally masculine spaces of science (with a problematic presumption that these are constructed as "gender neutral" spaces where people do not notice gender, as Samira stated). It raises a question about whether someone like Samira could have comfortably participated in the STEM club had she performed femininity, rather than distanced herself from such acts.

The finding that Samira's identification with and participation in science appeared to be negotiated through a rejection of femininity could be interpreted through looking at previous studies conducted with university-level female students. Researchers have argued that some female students, in order not to feel "out of place", restrained their performances of femininity (such as behaviours and physical appearance), often in ways that were uncomfortable and inauthentic [16,17]. Gonsalves has concluded from her findings that "to be recognized as a real physicist might mean to be invisible as a real woman, or it might also mean positioning oneself in opposition to other women" [17] (p. 519). A consideration of previous research work, along with the interpretation of Samira's accounts, suggests that there might be few opportunities to participate in science "intelligibly" as girls/women - and not as "substitute 
men" [69]. Walker has voiced concerns over the strategy involving girls and women to adjust their performances in order to fit in: "young women might construct an identity as 'one of the boys', but this identification will not dissolve gendered differences or obliterate male social power" [70] (see also $[54,66])$. An act of distancing oneself from performances of femininity raises concerns whether it is the invisibility of gender-or the invisibility of female-ness-that has enabled participation in science for someone like Samira.

The analysis of data also pointed at the concerns around the viability of gender not being noticed. As Asqa, one of the girls in the study, pointed out: "obviously people are going to look at your gender". West and Zimmerman have stated that "doing gender is unavoidable" [71] (p. 145). Behaviours and performances are recognised in relation to gender attributions, and "there are no contemporary humans who escape gendering" [27] (p. 57). Once a gender attribution is established and a person is identified as male or female, their behaviours are understood and judged by those around them with a reference to this label [72,73]. To exemplify one such instance, wanting to be in control of a group work activity might be perceived as "strategic" for a boy, but "manipulative" for a girl [72] (p. 9). While the discursive strategy of rendering gender invisible could be interpreted as supporting Samira to manage the "impossibility" of being a female participant in the science club, the question remains whether Samira would be able to negate her female body longer-term, and be viewed by others in a way where her female body would not get noticed (and hence, would not be in conflict with science).

Previous research has argued that a woman who is "the only one" in a male-dominated space is likely to stand out and attract unfavourable attention. Faulkner [74], who researched gender issues in the male-dominated field of engineering, has stressed that there is often an expectation of a gender norm, and that people tend to notice when something or someone stands out. In the case of her work, these were female engineers. Being the only woman has been argued to be unlikely to allow for "invisibility", but instead attracts the "wrong" kind of attention [75]. The issue of standing out, in a way that might be undesirable, could be amplified for those from minority ethnic groups, who are likely to struggle even more in establishing the "ordinariness" that would enable them to find a comfortable fit with the science community [76]. In Malone and Barabino's [18] study, the women who felt they were "the only one" in the science laboratories experienced a form of invisibility, albeit in a way of being ignored, excluded, and kept out of the loop for being regarded as unequal members of the scientific community, due to their different gender and ethnic/cultural background. Following an intersectional approach, I argue that it is crucial to consider not only girls' performances of gender, but also how gender intersects with other social axes that might further complicate their identification with science. Samira, a working-class Muslim girl, might experience challenges in predominantly white, middle-class, and male science environments.

Finally, considering the "race"- or colour-blindness ideology offers a further insight into why a discursive strategy of rendering gender invisible could be problematic. The idea of "race"-blindness is a political stance, arguing that no distinction should to be made on the basis of one's "race". This ideology was at the heart of the civil rights movement of the 1960s, aiming to end discrimination against African-Americans in the U.S. While such policies were important in abolishing overt discrimination practices, such as in relation to higher education access and employment opportunities, opponents have warned that making "race" invisible may actually reinforce structural racism and the (white) privilege of the dominant groups. Furthermore, this approach might disregard the tools for addressing the issues of structural racism and social inequalities [77]. In a similar way, gender-blindness approach could be seen as promoting equality, through not making any distinctions or not discriminating on the basis of someone's gender, but this approach is likely to make it difficult to identify and acknowledge the persisting structural oppressions, as "[g]ender blindness is the failure to recognise that the role and responsibilities of women/girls and men/boys are ascribed to, or imposed upon them in specific social, cultural, economic and political contexts." [78] The discourse of rendering gender invisible might risk allowing and perpetuating the status quo of unequal social relations in science, where only 
a narrow range of identity performances are accepted as legitimate. Those not willing or comfortable to participate in legitimised ways could thus encounter difficulties in participating in science.

\subsection{Discursive Strategy Two: Drawing Attention to the Presence of Women in Science}

The second discursive strategy involved drawing attention to the presence of women in science. Examples of women in science appeared to serve as evidence that it is no more difficult for girls to participate and succeed in science than it is for boys, as it is suggested by Dorota's interview response below. Dorota was a high-achieving science student, who wanted to become an astronomer or a doctor. She spoke at length about her "love" of science and said with confidence that she "definitely" considered herself to be a "science person". When I asked her about any differences between boys and girls in terms of science participation, she mentioned her role model Marie Curie as an example of how women have contributed to science.

Me: Do you think boys are more likely to go into science than girls? What do you think about that?

Dorota: ... it is stereotypical to think that, because many of the great scientists are boys. But then there's also scientists like, I think her name's Madam, oh God, the one that found out about cancer through getting radiation or something. Madam Curie or something like that.

\section{Me: Marie Curie?}

Dorota: Yeah, so she's also a big inspiration to me, because she's a woman and all that. So I don't think boys are more likely [to go into science], I just think that boys are more famous for some reason, I don't know why ... (Interview, June 2015)

I interpret Dorota's remarks as supporting her in constructing her own participation in science as more "intelligible" (suitable for girls, as indicated with examples of women in science). For Dorota, the presence of women like Marie Curie in science appeared to suggest that women were just as likely as men to pursue science trajectories. Other girls in the study similarly drew attention to female scientists as a way of justifying the (equal) opportunities for women to participate in science. Aliyah, for instance, argued that it was clear that women can be as successful and as likely to participate in science, stating, "I see this fact that like women have made, like, bullet proof vests" to illustrate her point.

While knowing about women in science helped the girls to construct science as more open to people regardless of their gender, most struggled to recall anyone but Marie Curie, an archetypal example of a woman in science [79] (and as Dorota's quotes above illustrates, struggling to even remember Madame Curie's actual name). While the girls showed agency to resist the dominant discourse of science as more for men, they appeared to have lacked the knowledge and understanding to do so, relying on few outdated examples of women succeeding in science. The interviews with participating teachers provide some explanation for this. Mr. Bramley, for example, admitted that he rarely mentioned female scientists during the science lessons he taught, because he himself struggled to find relevant information to draw upon. Mr. Cohen noted that his teaching, and examples he shared with his class, generally resonated more with his male than his female students, admitting that his lessons were "quite male-centred, they appeal to boys more than they do to girls". While not surprising-as research has found that mainstream science curricula tend to include fewer girls' interests and values than boys' [14,47] — the male focus, together with the lack of representation of women in science, made this discursive strategy challenging for the girls in this study.

Increasing the visibility of women in science has been at the heart of many programmes aiming to encourage more girls into science. This study's data analysis suggests that the advantages of knowing about women in science, however, could easily be dismissed by the reality of experience and 
participation figures, such as when Samira said that "there are more scientists that are boys than girls". There is a disjuncture between an egalitarian discourse of science on the one hand, and gender inequalities in actual STEM jobs on the other. Larisa articulated that "it could be quite tough for females to be scientists ... I think it kind of puts women off, how many men they would have to like contend with". The girls were also not always able to articulate the roots of such participation inequalities. As Dorota remarked, "boys are more famous for some reason, I don't know why". The goal of most "role models" programmes is to present women in diverse science-related jobs, often attending to aspects of their personal lives, to show that women are able to successfully combine work and family [80,81]. The underlying assumption seems to be that the barrier to girls' non-participation in science lies in the lack of exposure to and knowledge about women in science. A more diverse representation of scientific workforce is clearly important (although while pictorial representations include diversity in terms of gender and ethnicity, social class remains a hidden factor [82]). Programmes aiming to showcase successful women in science, however, tend to paint a rather uncritical picture of science, in that there is often little or no reference to structural difficulties permeating the field of science in such programmes. As Hazari and her colleagues [83] have argued, simply discussing the work of female scientists may not have a significant impact on how interested the girls were in engaging with the subject in the future, without also explicitly addressing female underrepresentation (see Conclusions for a further elaboration on this). Knowing about women in science might therefore have limited potential to help girls from working-class backgrounds identify with science, especially as it is often the reality and not just a stereotype that science environments continue to be dominated by men, and could hence be "tough" for girls to fit in, as Larisa pointed out.

\subsection{Discursive Strategy Three: Reframing "Science People" as Nurturing and Caring}

The third discursive strategy that the girls drew on to identify with science was reframing "science people" as nurturing and caring. Asqa said that they "help people, like they want to save lives" and Amna commented that "science people" cared about animals and the environment, and were "really eco-friendly". The notion of nurture and care appeared to be central in these girls' conceptualisation of what it meant to be a "science person". The notion of nurture and care also extended to their aspirations. Asqa, for instance, wanted to become a doctor, a pharmacist, or a dentist. This discursive strategy is interesting, because previous research has argued that girls' perception of science as non-nurturing and non-caring (and thus not feminine) presented a key challenge for many girls to identify with science. The literature has argued that girls negotiated their identification with the subject through performing femininity in less visible ways [1,84], or even performing masculinity [16], in order to better align their own performances with those considered integral to science.

While reframing "science people" as nurturing and caring made identifying with science more "intelligible" for Amna and Asqa, data analysis raises concerns about the extent to which this discursive strategy was inclusive of all science. Sharifa's account, for instance, suggests a disjunction between some science for all and other science just for men. She argued that boys and girls "can do the same thing in science", illustrating her point with an example of a science teacher: "If you want to be a science teacher you can be a girl or a boy, it's no different. Your gender ain't different to what job you're doing." However, when considering highly masculinised professions, like engineering, her response implicated a tension with typical, desirable femininity.

Boys, they like to get dirty ... but then some girls don't like to get dirty and then engineering, you will get dirty and stuff, you'll get like all messy, but then boys, they don't really mind, they just like, they just get on with their job. Girls, if they get something on their clothes, then they start moaning ...

-Sharifa (Interview, April 2015)

Sharifa associated engineering with "getting dirty" and hence incompatible with femininity and "unintelligible" for girls. By speaking about girls this way, I suggest that Sharifa attributed 
these qualities to herself [85], positioning herself against "dirty" engineering. Through the discursive alignment of science and STEM with masculinity, Sharifa constructed some science as not suitable for her. While the discursive strategy of reframing "science people" as nurturing and caring enabled two of the girls to consider themselves "sciencey", dominant associations with masculinity made it difficult for others to take up this position-despite enjoying science and aspiring to jobs involving science.

The girls made a discursive distinction between nurturing and caring "girl science" and difficult and technical "boy science" [86], whereby only the former was considered "intelligible" for them to perform and participate in, and the latter less so. A quote from Rifat illustrates this distinction, as she related some aspects of science to typically girls' interests and professions (biology and female nurses), and other aspects to boys' (physics and cars):

... you need like physics and all that for cars and stuff like that. You know, typically boys like cars ... Biology is more like human, you can become doctors and stuff like that with biology and then you see like female nurses...

-Rifat (Interview, June 2015)

The distinction between "physics for boys" and "biology for girls" is consistent with the dominant gendering of science subjects $[49,54,87,88]$ and participation figures (girls' participation is the lowest in physics and the highest in biology, see [89-91]). Most of the science-aspiring girls in this study $(n=10 / 15)$ mentioned professional fields where women participate in similar or greater numbers than men, such as in healthcare. The girls' science-related aspirations could be regarded as motivated by caring for and helping others, which research has previously found to be a strong motivator for many girls' career aspirations [36,92]. The link between healthcare and femininity has also been discussed elsewhere [93,94], with care being integral to dominant constructions of femininity [53,95-97]. According to Skeggs [98], the centrality of care could be interpreted as having particular importance for girls/women from working-class backgrounds, who are constructed as needing to prove their respectability through caring performances. The girls' uptake of caring (feminine) subjectivities and exclusion of more technical aspects of science made identification with science difficult.

The emphasis on the feminine aspects of science can be observed in many programmes aimed at encouraging girls and women in science. An EU programme called "Science-It's a girl thing" [99] is one such example; it centred on presenting typically feminine interests and performances as a strategy to invite girls into science (the programme's flagship video included a group of teenage girls dancing around a laboratory in stilettos and applying makeup). The premise seemed to be to show girls that femininity is compatible with science, which would presumably encourage them into the discipline. However, programmes that have focused on girls specifically through including typically "girly" attributes run the risk of essentialising girls and fueling the binary opposition of "girls do this" and "boys do that" [100]. Girls are also not a homogenous group, and differences among girls might be as profound as those between girls and boys [42]. Portraying girls in a narrow manner and failing to consider intersectionality of gender with other social axes is likely to be exclusive of the diversity within the grouping. Considering the findings from this study, it is difficult to imagine that an initiative like "Science-It's a girl thing", which portrays a particular version of femininity (arguably also interacting with social class through its emphasis on consumer-oriented performances), would be successful in supporting the identification with science among the girls involved in this study. Someone like Samira, who resisted performances of "girly" femininity (see above), would probably not feel encouraged into science through a narrow framing of femininity that was presented in the programme. I suggest that, similarly, an initiative focused on presenting science as nurturing and caring might fail to be inclusive of the diversity of girls. Finally, programmes focusing on feminising science also risk reproducing and reinforcing the dominant binaries and "gender polarization" of science, rather than disrupting and broadening it $[54,101]$. 


\subsection{Discursive Strategy Four: Cultural Discourse of Desirability of Science}

The final discursive strategy identified in this study is the cultural discourse of desirability of science. This discourse was noted among the girls from South Asian backgrounds (Amna, Asqa, and Sharifa were of Pakistani and Bangladeshi backgrounds), all of whom spoke about high parental expectations and encouragement for education with a specific focus on science.

Asian parents, they want you to get good levels 'cause they want you to get a good job and succeed.' ... My dad wants me to be a doctor ... he left his school, 'cause he had to go and work and so then he didn't go to college, but then he wants us to go to college and university and stuff.

—Sharifa (Interview, June 2015)

My parents, like all these Asian parents, they want you to be either a doctor, a lawyer or an engineer.

-Asqa (Interview, June 2015)

I think it's common with like every parent really, it's like they want all their children to be like doctors or lawyers or something with a well-paid job, but I think most of them depend on science, because science gives such a big range of jobs and everything.... [Mum] wants me to do something to do with science or something like that, because, obviously, it's well paid and everything.

-Amna (Interview, June 2015)

These quotes suggest a cultural (South Asian) discourse of science as a desirable subject, which I interpret as supporting the girls' identification with the subject. The girls appeared to have internalised science as a desirable future aspiration. These findings resonate with Archer et al., who argued that the "interplay between cultural discourses around gender and science in which science is configured as sexually appropriate" [84] (p. 980) plays an important role in identification and engagement with science for many South Asian girls. While femininity tends to be less compatible with the subjectivities of science, the "otherness" of ethnicity can help provide the exceptions to this [54]. The South Asian discourse of desirability of science stood in contrast with discourses articulated by other girls, particularly for girls from white, British, working-class backgrounds. Caitlin (a white, British, working-class girl), for instance, spoke about her mum constantly being "surprised" when she did well at science in school, and construed that an aspiration to working in the entertainment industry as more desirable than pursuing higher education or science.

The emphasis on science and "respectable", well-paid careers like medicine was tied with a discourse of social mobility and gaining status within extended family and ethnic communities. High aspirations were motivated by parents' desire for their daughters to achieve financial stability, in some cases reflecting their own lack of educational opportunities [102]. Archer and Francis have previously argued that such ambitions reflect a "habitus in which the expectation of mobility forms a central narrative" [103] (p. 42). Previous studies have found that careers in medicine tend to be a particularly desirable aspiration among South Asian students in the U.K. [104], with science playing an integral part in the path to success. South Asian students have also been argued to have particularly favourable dispositions towards science [84,105], which is evident also in high levels of participation of females in STEM subjects in several majority Muslim countries (Amna, Asqa, and Sharifa were Muslim) $[106,107]$. Among the girls in this study, pursuing careers such as medicine was seen as leading to positive recognition by their families and their community. Asqa commented that her parents encouraged her and her siblings to choose professions like medicine "because they want to feel proud that they have a son or daughter like that". She added that her parents, like other Asian parents, liked to boast about their children's academic success ("It'll be like, 'oh, my child, she's so good, look!'”). Shah et al. have found, in their U.K.-based study with South Asian students, that many 
of them "were acutely aware of the respect and status higher education and professional qualifications would confer on the family" [108] (p. 1114) (see also [109]). While the girls in this study were adamant that their parents would never "force" them into careers they would not enjoy (Asqa said, "they're more like you can choose whatever you want, they don't force us or anything"), they appeared to have a strong understanding that following desired academic and professional paths would lead to positive recognition for themselves and their families.

\section{Conclusions}

This paper has presented discursive strategies that supported ethnically diverse, working class girls aged 11-13 to identify with science. The first two-rendering gender invisible and drawing attention to the presence of women in science-aligned with gender equality and equal opportunity thinking. Gender was regarded as a non-issue, as not playing a role in influencing science participation. The analysis of data, however, raised concerns about what performances girls were expected to enact in order to fit into the presumed gender-neutral spaces of science, as well as challenged the extent to which knowing about women in science can support diverse girls in negotiating their identity work. The third discursive strategy—reframing "science people" as nurturing and caring-made science subjectivities more "intelligible", but risked being exclusive of more masculinised areas, such as physical science and engineering. Consequently, the girls' identification and engagement with science largely remained confined to the typically feminine domains, arguably reproducing the existing gender binaries. Finally, the girls' identification with science was also supported by South Asian cultural discourses that constructed science as a desirable subject, due to its perceived potential to lead to financially stable and "respectable" occupations. While these discourses positively supported the girls' identification with science to an extent, it is important to consider that the girls had to do a substantial amount of identity work to "achieve" this, and even then, their identification and engagement with science largely remained confined to the biological sciences and professions centred on nurture and care.

The findings of this study provide some points of reflection for the interventions commonly adopted to encourage more girls/women into science. In particular, this paper has discussed "role model" interventions (mapped onto the discourse of drawing attention to women in science) and "feminising science" programmes (related to reframing science as nurturing and caring, and thus symbolically feminine). The underlying assumptions of these actions seem to be that the barriers to girls' participation in science is either the lack of visibility and knowledge of women in science, or the overly masculine representation of science. Knowing about a few women in science and considering some science-related jobs as compatible with performances of femininity appeared insufficient to help the girls in this study understand and navigate participation in science. Based on the findings of this study, I argue that focusing on "image" issues might be inadequate, as others have noted [100]. The egalitarian discourse that everyone can participate and succeed in science if they put their skills and determination to work offers few resources and strategies for girls to leverage when self-improvement does not suffice $[16,110]$.

How might the findings presented in this paper contribute to informing future actions towards achieving greater gender equality and more equitable opportunities for all young people? The challenges related to gender inequalities are clearly multiple, and permeate all levels of education into employment, hence there is no "magic formula" [111]. The findings of this study, however, implicate that it could be beneficial to acknowledge and explicitly address the inequalities in science participation [100,112], such as through programmes focused on showcasing women in science. Research has found that discussing female underrepresentation in science can have a positive impact on girls' identification with the subject and their career aspirations $[83,113]$. Such approach could better prepare girls for challenges they may face upon embarking on a scientific career [108]. Further, this study adds to the arguments made previously, that inviting girls into supposedly gender-neutral science might not lead to greater equity without changing the existing structures $[1,114]$. For instance, 
there appeared to be limited discursive spaces available for the girls to engage with science, challenging the idea whether engagement was possible through performances of femininity. I echo social justice-oriented education research work that stresses that the onus should be on changing the dominant culture of science, i.e., to broaden the practice and make more heterogeneous performances and experiences legitimate and valuable, not on changing the girls, who are often seen as "failing" to enter science for holding limited, narrow views about science. In the recent years, there have been a number of programmes attempting to engage more diverse young people with science and help them to see science as for them, with promising outcomes (e.g., $[14,115,116])$. This study hopes to contribute to furthering this work and making science education more equitable for all young people.

Acknowledgments: This study was supported by the Rosalind Driver Scholarship fund at King's College London. I would like to thank my colleagues on the Enterprising Science project (Louise Archer, Emily Dawson, Jennifer DeWitt, Justin Dillon, Heather King, Ada Mau, Effrosyni Nomikou, Elaine Regan, Amy Seakins and Billy Wong) for their support, in particularly Louise and Emily who supervised my doctoral work. I would also like to express my gratitude to Michael Reiss and Heather Mendick for our discussions about my analysis, and colleagues who provided feedback on the earlier versions of this paper that I presented at the 2017 European Science Education Research Association conference in Dublin. Finally, I want thank the teachers, students and their parents who made it possible for me to carry out this study.

Conflicts of Interest: The author declares no conflict of interest.

\section{References}

1. Brickhouse, N.W.; Potter, J.T. Young women's scientific identity formation in an urban context. J. Res. Sci. Teach. 2001, 38, 965-980. [CrossRef]

2. Carlone, H.B.; Scott, C.M.; Lowder, C. Becoming (less) scientific: A longitudinal study of students' identity work from elementary to middle school science. J. Res. Sci. Teach. 2014, 51, 836-869. [CrossRef]

3. Calabrese Barton, A.; Kang, H.; Tan, E.; O’Neill, T.B.; Bautista-Guerra, J.; Brecklin, C. Crafting a future in science tracing middle school girls' identity work over time and space. Am. Educ. Res. J. 2012, 50, 37-75. [CrossRef]

4. Archer, L.; Dawson, E.; DeWitt, J.; Godec, S.; King, H.; Mau, A.; Nomikou, E.; Seakins, A. Killing curiosity? An analysis of celebrated identity performances among teachers and students in nine london secondary science classrooms. Sci. Educ. 2017, 101, 741-764. [CrossRef]

5. Carlone, H.B. (Re)producing good science students: Girls' participation in high school physics. J. Women Minor. Sci. Eng. 2003, 9, 17-34. [CrossRef]

6. Calabrese Barton, A.; Tan, E. ‘We be burnin'! Agency, identity, and science learning. J. Learn. Sci. 2010, 19, 187-229. [CrossRef]

7. Henriksen, E.; Dillon, J.; Ryder, J. Understanding Student Participation and Choice in Science and Technology Education; Springer: Dordrecht, The Netherlands, 2015.

8. Murphy, C.; Beggs, J. Children's perceptions of school science. Sch. Sci. Rev. 2003, 84, 109-116.

9. Osborne, J.; Simon, S.; Collins, S. Attitudes towards science: A review of the literature and its implications. Int. J. Sci. Educ. 2003, 25, 1049-1079. [CrossRef]

10. Archer, L.; Osborne, J.; DeWitt, J.; Dillon, J.; Wong, B.; Willis, B. ASPIRES: Young People's Science and Career Aspirations, Age 10-14; King's College London: London, UK, 2013.

11. Brotman, J.S.; Moore, F.M. Girls and science: A review of four themes in the science education literature. J. Res. Sci. Teach. 2008, 45, 971-1002. [CrossRef]

12. Archer, L.; DeWitt, J.; Osborne, J.; Dillon, J.; Willis, B.; Wong, B. 'Doing' science versus 'being' a scientist: Examining 10/11-year-old schoolchildren's constructions of science through the lens of identity. Sci. Educ. 2010, 94, 617-639. [CrossRef]

13. Thompson, J. Engaging girls' sociohistorical identities in science. J. Learn. Sci. 2014, 23, 1-55. [CrossRef]

14. Calabrese Barton, A.; Tan, E.; Rivet, A. Creating hybrid spaces for engaging school science among urban middle school girls. Am. Educ. Res. J. 2008, 45, 68-103. [CrossRef]

15. Zacharia, Z.; Calabrese Barton, A. Urban middle-school students' attitudes toward a defined science. Sci. Educ. 2004, 88, 197-222. [CrossRef] 
16. Danielsson, A.T. Exploring woman university physics students 'doing gender' and 'doing physics'. Gend. Educ. 2011, 24, 25-39. [CrossRef]

17. Gonsalves, A. 'Physics and the girly girl-There is a contradiction somewhere': Doctoral students' positioning around discourses of gender and competence in physics. Cult. Stud. Sci. Educ. 2014, 9, 503-521. [CrossRef]

18. Malone, K.; Barabino, G. Narrations of race in stem research settings: Identity formation and its discontents. Sci. Educ. 2009, 93, 485-510. [CrossRef]

19. Ulriksen, L.; Madsen, L.M.; Holmegaard, H.T. What do we know about explanations for drop out/opt out among young people from STM higher education programmes? Stud. Sci. Educ. 2010, 46, 209-244. [CrossRef]

20. Carlone, H.B.; Johnson, A. Understanding the science experiences of successful women of color: Science identity as an analytic lens. J. Res. Sci. Teach. 2007, 44, 1187-1218. [CrossRef]

21. Settles, I.H.; Jellison, W.A.; Pratt-Hyatt, J.S. Identification with multiple social groups: The moderating role of identity change over time among women-scientists. J. Res. Personal. 2009, 43, 856-867. [CrossRef]

22. Institute of Physics. It's Different for Girls: The Influence of Schools; Institute of Physics: London, UK, 2012.

23. Institute of Physics. Opening Doors: A Guide to Good Practice in Countering Gender Stereotyping in Schools; Institute of Physics: London, UK, 2015.

24. WISE. People Like Me. Available online: https://www.wisecampaign.org.uk/resources/2015/09/not-forpeople-like-me-research-summary (accessed on 11 June 2016).

25. Calabrese Barton, A.; Yang, K. The culture of power and science education: Learning from Miguel. J. Res. Sci. Teach. 2000, 37, 871-889. [CrossRef]

26. Lemke, J.L. Articulating communities: Sociocultural perspectives on science education. J. Res. Sci. Teach. 2001, 38, 296-316. [CrossRef]

27. Harding, S. The Science Question in Feminism; Cornell University Press: Ithaca, NY, USA, 1986.

28. Sainsbury, D. The Race to the Top: A Review of Government's Science and Innovation Policies; Her Majesty's Stationery Office: London, UK, 2007.

29. HMT. Science and Innovation Investment Framework 2004-2014; The Stationary Office: London, UK, 2004.

30. CBI. Set for Growth: Business Priorities for Science, Engineering and Technology. Available online: http:/ / www.cbi.org.uk/media/935312/2010.08-set-for-growth.pdf (accessed on 31 March 2014).

31. Walkerdine, V. Femininity as performance. Oxf. Rev. Educ. 1989, 15, 267-279. [CrossRef]

32. Keller, E.F. Reflections on Gender and Science; Yale University Press: New Haven, CT, USA, 1985.

33. Harding, S. Women, science, and society. Science 1998, 281, 1599-1600. [CrossRef]

34. Brickhouse, N.W. Embodying science: A feminist perspective on learning. J. Res. Sci. Teach. 2001, 38, $282-295$. [CrossRef]

35. DeWitt, J.; Archer, L.; Osborne, J. Nerdy, brainy and normal: Children's and parents' constructions of those who are highly engaged with science. Res. Sci. Educ. 2012, 43, 1-22. [CrossRef]

36. Archer, L.; DeWitt, J.; Osborne, J.; Dillon, J.; Willis, B.; Wong, B. 'Not girly, not sexy, not glamorous': Primary school girls' and parents' constructions of science aspirations. Pedag. Cult. Soc. 2013, 21, 171-194. [CrossRef]

37. Francis, B. The role of the boffin as abject other in gendered performances of school achievement. Sociol. Rev. 2009, 57, 645-669. [CrossRef]

38. Mendick, H.; Francis, B. Boffin and geek identities: Abject or privileged? Gend. Educ. 2012, 24, 15-24. [CrossRef]

39. Archer, L.; Dawson, E.; DeWitt, J.; Seakins, A.; Wong, B. “Science capital”: A conceptual, methodological, and empirical argument for extending Bourdieusian notions of capital beyond the arts. J. Res. Sci. Teach. 2015, 52, 922-948. [CrossRef]

40. Archer, L.; DeWitt, J.; Osborne, J.; Dillon, J.; Willis, B.; Wong, B. Science aspirations, capital, and family habitus: How families shape children's engagement and identification with science. Am. Educ. Res. J. 2012, 49, 881-908. [CrossRef]

41. Archer, L.; DeWitt, J.; Wong, B. Spheres of influence: What shapes young people's aspirations at age 12/13 and what are the implications for education policy? J. Educ. Policy 2013, 1-28. [CrossRef]

42. Brickhouse, N.W.; Lowery, P.; Schultz, K. What kind of a girl does science? The construction of school science identities. J. Res. Sci. Teach. 2000, 37, 441-458. [CrossRef] 
43. DeWitt, J.; Osborne, J.; Archer, L.; Dillon, J.; Willis, B.; Wong, B. Young children's aspirations in science: The unequivocal, the uncertain and the unthinkable. Int. J. Sci. Educ. 2011, 35, 1037-1063. [CrossRef]

44. Butler, J. Bodies That Matter: On the Discursive Limits of Sex; Routledge: London, UK, 1993.

45. Butler, J. Gender Trouble: Feminism and the Subversion of Identity; Routledge: London, UK, 1999.

46. Archer, L.; Francis, B. Understanding Minority Ethnic Achievement: Race, Gender, Class and 'Success'; Routledge: Oxon, UK, 2007.

47. Calabrese Barton, A.; Brickhouse, N. Engaging girls in science. In The Sage Handbook of Gender and Education; Skelton, C., Francis, B., Smulyan, L., Eds.; Sage: London, UK, 2006; pp. 221-236.

48. Renold, E. Girls, Boys, and Junior Sexualities; Routhledge Falmer: London, UK, 2005.

49. Walkerdine, V. Schoolgirl Fictions; Verso Books: London, UK, 1990.

50. Walkerdine, V. Daddy's Girl: Young Girls and Popular Culture; Harvard University Press: Cambridge, MA, USA, 1998.

51. Reay, D. Class Work: Mothers' Involvement in Their Children's Primary Schooling; University College London Press: London, UK, 1998.

52. Hill Collins, P. Black Feminist thought: Knowledge, Consciousness, and the Politics of Empowerment, 2nd ed.; Routledge: London, UK, 2002.

53. Francis, B. Boys, Girls, and Achievement: Addressing the Classroom Issues; Routledge: London, UK, 2000.

54. Hughes, G. Exploring the availability of student scientist identities within curriculum discourse: An anti-essentialist approach to gender-inclusive science. Gend. Educ. 2001, 13, 275-290. [CrossRef]

55. Erel, U. Migrating cultural capital: Bourdieu in migration studies. Sociology 2010, 44, 642-660. [CrossRef]

56. Platt, L. Migration and Social Mobility: The Life Chances of Britain's Minority Ethnic Communities; Policy Press: Bristol, UK, 2005.

57. Modood, T. Capitals, ethnic identity and educational qualifications. Cult. Trends 2004, 13, 87-105. [CrossRef]

58. Cronin, A. Focus groups. In Researching Social Life, 3rd ed.; Gilbert, N., Ed.; Sage: London, UK, 2001; pp. 226-244.

59. Bryman, A. Social Research Methods; Oxford University Press: Oxford, UK, 2012.

60. Denscombe, M. The Good Research Guide: For Small-Scale Social Research Projects, 4th ed.; Open University Press: Maidenhead, UK, 2010.

61. Wong, B. Careers "from" but not "in" science: Why are aspirations to be a scientist challenging for minority ethnic students? J. Res. Sci. Teach. 2015, 52, 979-1002. [CrossRef]

62. Burman, E.E.; Parker, I.E. Discourse Analytic Research: Repertoires and Readings of Texts in Action; Routledge: London, UK, 1993.

63. Davies, B. Shards of Glass: Children Reading and Writing beyond Gendered Identities; Allen and Unwin: Crows Nest, IN, USA, 1993.

64. Francis, B. Re/theorising gender: Female masculinity and male femininity in the classroom? Gend. Educ. 2010, 22, 477-490. [CrossRef]

65. Walkerdine, V.; Lucey, H.; Melody, J. Growing up Girl: Psycho-Social Explorations of Gender and Class; Palgrave: London, UK, 2001.

66. Francis, B.; Burke, P.; Read, B. The submergence and re-emergence of gender in undergraduate accounts of university experience. Gend. Educ. 2014, 26, 1-17. [CrossRef]

67. Godec, S. Urban Girls' Engagement with Science within Lessons, Class Visits and Family Visits to Science Museums: Interactions of Gender, Social Class and Ethnicity. Ph.D. Dissertation, King's College London, London, UK, 2017.

68. Archer, L.; DeWitt, J. Science aspirations and gender identity: Lessons from the ASPIRES project. In Understanding Student Participation and Choice in Science and Technology Education; Henriksen, E.K., Dillon, J., Ryder, J., Eds.; Springer: Dordrecht, The Netherlands, 2014; pp. 89-102.

69. Gilbert, J. Science and its 'other': Looking underneath 'woman' and 'science' for new directions in research on gender and science education. Gend. Educ. 2001, 13, 291-305. [CrossRef]

70. Walker, M. Engineering identities. Br. J. Sociol. Educ. 2001, 22, 75-89. [CrossRef]

71. West, C.; Zimmerman, D.H. Doing gender. Gend. Soc. 1987, 1, 125-151. [CrossRef]

72. Francis, B. Gender monoglossia, gender heteroglossia: The potential of Bakhtin's work for re-conceptualising gender. J. Gend. Stud. 2012, 21, 1-15. [CrossRef] 
73. Kessler, S.J.; McKenna, W. Gender: An Ethnomethodological Approach; University of Chicago Press: Chicago, IL, USA, 1978.

74. Faulkner, W. 'Nuts and bolts and people': Gender-troubled engineering identities. Soc. Stud. Sci. 2007, 37. [CrossRef]

75. Lynch, I.; Nowosenetz, T. An exploratory study of students' constructions of gender in science, engineering and technology. Gend. Educ. 2009, 21, 567-581. [CrossRef]

76. Ong, M. Body projects of young women of color in physics: Intersections of gender, race, and science. Soc. Probl. 2005, 52, 593-617. [CrossRef]

77. Bonilla-Silva, E. Racism without Racists: Color-Blind Racism and the Persistence of Racial Inequality in America; Rowman \& Littlefield: Lanham, MD, USA, 2017.

78. European Institute for Gender Equality. Gender Blindness. Available online: http://eige.europa.eu/rdc/ thesaurus / terms / 1157 (accessed on 24 October 2017).

79. Wise, P.M.; Simmons, E.H. Improving the experience of women in the science, technology, engineering, and mathematics professoriate. In Challenges in Higher Education Leadership: Practical and Scholarly Solutions; Antony, J.S., Cauce, A.M., Shalala, D.E., Eds.; Routledge: New York, NY, USA, 2017.

80. The Royal Society. Royal Society Website. Available online: https:/ / royalsociety.org (accessed on 10 October 2017).

81. GAPP. Gender Awareness Participation Process: Differences in the Choices of Science Careers; Fondazione IDIS: Naples, Italy, 2009.

82. Wright, A.; Michielsens, E.; Snijders, S.; Kumarappan, L.; Williamson, M.; Clarke, L.; Urwin, P. Diversity in STEMM: Establishing a Business Case; Westminster Business School: London, UK, 2014.

83. Hazari, Z.; Potvin, G.; Lock, R.M.; Lung, F.; Sonnert, G.; Sadler, P.M. Factors that affect the physical science career interest of female students: Testing five common hypotheses. Phys. Rev. Spec. Top.-Phys. Educ. Res. 2013, 9, 1-8. [CrossRef]

84. Archer, L.; DeWitt, J.; Osborne, J.; Dillon, J.; Willis, B.; Wong, B. 'Balancing acts': Elementary school girls' negotiations of femininity, achievement, and science. Sci. Educ. 2012, 96, 967-989. [CrossRef]

85. Due, K. Who is the competent physics student? A study of students' positions and social interaction in small-group discussions. Cult. Stud. Sci. Educ. 2014, 9, 441-459. [CrossRef]

86. Moreau, M.-P.; Mendick, H. Discourses of women scientists in online media: Towards new gender regimes? Int. J. Gend. Sci. Technol. 2012, 4, 4-23.

87. Harding, S. Whose Science? Whose Knowledge?: Thinking from Women's Lives; Cornell University Press: Ithaca, NY, USA, 1991.

88. Keller, E.F. How gender matters, or, why it's so hard for us to count past two. In Inventing Women: Science, Technology and Gender; Kirkup, G., Keller, L.S., Eds.; Open University Press: Cambridge, UK, 1992; pp. 42-56.

89. Smith, E. Staying in the science stream: Patterns of participation in a-level science subjects in the UK. Educ. Stud. 2011, 37, 59-71. [CrossRef]

90. Institute of Physics. Closing Doors: Exploring Gender and Subject Choice in Schools; Institute of Physics: London, UK, 2013.

91. Elias, P.; Jones, P.; McWhinnie, S. Representation of Ethnic Groups in Chemistry and Physics; Royal Society of Chemistry \& Institute of Physics: London, UK, 2006.

92. Francis, B. The gendered subject: Students' subject preferences and discussions of gender and subject ability. Oxf. Rev. Educ. 2000, 26, 35-48. [CrossRef]

93. Francis, B. Is the future really female? The impact and implications of gender for 14-16 year olds' career choices. J. Educ. Work 2002, 15, 75-88. [CrossRef]

94. Francis, B.; Hutchings, M.; Archer, L.; Melling, L. Subject choice and occupational aspirations among pupils at girls' schools. Pedag. Cult. Soc. 2003, 11, 425-442. [CrossRef]

95. Francis, B.; Skelton, C.; Read, B. The simultaneous production of educational achievement and popularity: How do some pupils accomplish it? Br. Educ. Res. J. 2010, 36, 317-340. [CrossRef]

96. Mendick, H. A beautiful myth? The gendering of being/doing 'good at maths'. Gend. Educ. 2005, 17, 203-219. [CrossRef]

97. Francis, B.; Skelton, C. Reassessing Gender and Achievement: Questioning Contemporary Key Debates; Routledge: Oxon, UK, 2005.

98. Skeggs, B. Formations of Class E Gender: Becoming Respectable; Sage: London, UK, 1997. 
99. European Commission. Science: It's a Girl Thing! Available online: http://science-girl-thing.eu/ (accessed on 11 June 2016).

100. Sinnes, A.T.; Løken, M. Gendered education in a gendered world: Looking beyond cosmetic solutions to the gender gap in science. Cult. Stud. Sci. Educ. 2014, 9, 343-364. [CrossRef]

101. Allegrini, A. Gender, stem studies and educational choices. Insights from feminist perspectives. In Understanding Student Participation and Choice in Science and Technology Education; Henriksen, E., Dillon, J., Ryder, J., Eds.; Springer: Dordrecht, The Netherlands, 2015.

102. Basit, T.N. Educational capital as a catalyst for upward social mobility amongst British Asians: A three-generational analysis. Br. Educ. Res. J. 2013, 39, 714-732. [CrossRef]

103. Archer, L.; Francis, B. Challenging classes? Exploring the role of social class within the identities and achievement of British Chinese pupils. Sociology 2006, 40, 29-49. [CrossRef]

104. Springate, I.; Harland, J.; Lord, P.; Wilkin, A. Why Choose Physics and Chemistry?: The Influences on Physics and Chemistry Subject Choices of BME Students; Institute of Physics: London, UK, 2008.

105. DeWitt, J.; Archer, L.; Osborne, J.; Dillon, J.; Willis, B.; Wong, B. High aspirations but low progression: The science aspirations-careers paradox amongst minority ethnic students. Int. J. Sci. Math. Educ. 2011, 9, 243-271. [CrossRef]

106. Ater Kranov, A.; DeBoer, J.; Abu-Lail, N. Factors affecting the educational and occupational trajectories of women in engineering in five comparative national settings. In Proceedings of the International Conference on Interactive Collaborative Learning, Dubai, UAE, 3-6 December 2014.

107. Abu-Lail, N.; Phang, F.; Ater Kranov, A.; Mohd-Yusof, K.; Olsen, R.; Williams, R.; Zainal Abidin, A. Persistent gender inequity in U.S. undergraduate engineering: Looking to Jordan and Malaysia for factors to their success in achieving gender parity. In Proceedings of the American Society for Engineering Education Annual Conference, San Antonio, TX, USA, 10-13 June 2012.

108. Shah, B.; Dwyer, C.; Modood, T. Explaining educational achievement and career aspirations among young British Pakistanis: Mobilizing 'ethnic capital'? Sociology 2010, 44, 1109-1127. [CrossRef]

109. Ahmad, F. Modern traditions? British Muslim women and academic achievement. Gend. Educ. 2001, 13, 137-152. [CrossRef]

110. Erwin, L.; Maurutto, P. Beyond access: Considering gender deficits in science education. Gend. Educ. 1998, 10, 51-69. [CrossRef]

111. Walkerdine, V. Counting Girls Out: Girls and Mathematics; Falmer Press: London, UK, 1998.

112. Mendick, H. Gender and physics: A sociological approach. Phys. Educ. 2016, 51, 1-6. [CrossRef]

113. Hazari, Z.; Sonnert, G.; Sadler, P.; Shanahan, M. Connecting high school physics experiences, outcome expectations, physics identity, and physics career choice: A gender study. J. Res. Sci. Teach. 2010, 47, 978-1003. [CrossRef]

114. Howes, E.V. Connecting Girls and Science: Constructivism, Feminism, and Education Reform; Teachers College Press: New York, NY, USA, 2002.

115. Archer, L.; Dawson, E.; DeWitt, J.; Godec, S.; King, H.; Mau, A.; Nomikou, E.; Seakins, A. Using Bourdieu in practice? Urban secondary teachers' and students' experiences of a Bourdieusian-inspired pedagogical approach. Br. J. Sociol. Educ. 2017, 1-16. [CrossRef]

116. Hill, C.; Corbett, C.; St Rose, A. Why So Few? Women in Science, Technology, Engineering, and Mathematics; American Association of University Women: Washington, DC, USA, 2010.

(c) 2018 by the author. Licensee MDPI, Basel, Switzerland. This article is an open access article distributed under the terms and conditions of the Creative Commons Attribution (CC BY) license (http://creativecommons.org/licenses/by/4.0/). 